досліджень жіноча мова асоціюється 3 більш вузьким тональним діапазоном); в) переважання низхідних термінальних тонів та базисних типів шкал (в той час, як за даними гендерних досліджень в жіночій мові переважають висхідні тони і поєднання різних типів шкал).

В цілому всім жінкам-інформантам притаманний коопераційний стиль ведення бесіди: вони не перебивають співрозмовника і роблять паузи в кінці смислових відрізків, надаючи інтерв'юеру можливість задати наступне питання. Дані тактики характерні для жіночого голосу і не характерні для чоловічого, в якому присутня велика кількість переривань співрозмовника 3 метою домінування в бесіді. Просодичні засоби у взаємодії з лексико-синтаксичними засобами сприяють реалізації іміджу сучасної жінки, яка домоглася високого професійного статусу.

\title{
Література:
}

1. Карасик В.И. Язык социального статуса. М.: Гнозис, 2002. 333 с.

2. Шевченко Т.И. Теоретическая фонетика английского языка. М. : Высшая школа, 2009. 191 с.

3. Giles H., Bourhis R., Taylor D.M. Towards a theory of a language in ethnic group relations. Language, ethnicity and intergroup relations / ed. H. Giles. London: Academic Press, 1977. P. 307-348.

DOI https://doi.org/10.30525/978-9934-588-90-7-40

\section{СТРУКТУРНІ ХАРАКТЕРИСТИКИ АНГЛОМОВНИХ ВІЙСЬКОВИХ ТЕРМІНІВ}

\author{
Лемешко О. О.
}

аспірант кафедри германських мов і перекладознавства Дрогобиџький державний педагогічний університет імені Івана Франка м. Дрогобич, Львівська область, Украӥна

Постановка проблеми. Об'єктом даного дослідження є англомовні військові терміни, що використовуються в збройних силах Сполучених Штатів Америки, Великої Британії та Канади. Дані терміни, загальна кількість яких становить 1000 одиниць були відібрані зі спеціалізованих словників таких, як DOD Dictionary of Military and Associated Terms, Military dictionary by William Duane.

Предметом дослідження є структурні характеристики англомовних військових термінів та їх словотвірні моделі. 
Аналіз дослідження. Термін, як лінгвістичний феномен неодноразово ставав предметом дослідження лінгвістів, не тільки в галузі термінознавства, але й загального мовознавства (А. Е. Левицький, В. Ф. Новодранова, Е. Ф. Скороходько). Питання теоретичних дослідженнь ролі терміна в науковому дискурсі (Л. В. Мисик, С. М. Рибачок, Т. Г. Скопюк, Е. Ф. Скороходько) та зіставлення термінів різних мов під кутом перекладацької проблематики (Т. П. Андрієнко, М. М. Антонович, Ф. А. Циткіна) також були розглянуті. Незважаючи на значну кількість праць, присвячених науковій термінології, окремі терміносистеми і досі залишаються недослідженими. До таких належить, зокрема, англомовна військова термінологія. Наукова новизна дослідження полягає у дослідженні структурних характеристик англомовних військових термінологічних систем США, Великої Британії, Канади.

Метою $є$ виявлення найтиповіших структурних характеристик термінотворення у сучасних військових терміносистемах Сполучених Штатів Америки, Великої Британії та Канади. У ході роботи використовувалися наступні методи дослідження - метод лінгвістичного опису та статистичний метод.

Виклад основного матеріалу. В першу чергу важливо окреслити та дати визначення явищу терміну та терміносистеми. «Термін - це слово чи усталене словосполучення, яке виражає спеціальне поняття науки, техніки або іншої галузі людської діяльності та має дефініцію, яка розкриває ті ознаки цього поняття, що є релевантними саме для цієї галузі» [4, с. 7]. «Сукупність термінів, що стосуються певної галузі науки, техніки чи іншої сфери людської діяльності, утворюють галузеву термінологію або термінологічну систему» [3, с. 11]. Фахова підмова, зокрема, військова, $\epsilon$ особливою формою існування мови, що має професійну спрямованість. Її найбільш рухомим компонентом $\epsilon$ лексична підсистема, що має польовий характер, тобто іiі структура організована за принципом поля, в якому $\epsilon$ центр із його ядром (термінологія) і периферія (субстандартна лексика). Військова лексика $\epsilon$ сукупністю мовних одиниць, що поєднуються спільним змістом і відображають понятійну, предметну та функціональну схожість явищ, які вони позначають. Склад військової лексики розглядається в лінгвістиці з різних точок зору.

Л. Л. Нелюбін розподіляє військову лексику на три основні групи: військову термінологію, військово-технічну термінологію та емоційно забарвлену військову лексику [2, с. 13]. У розумінні військового термін Нелюбін Л.Л. виходить із лінгвістичного уявлення про терміни як слова i словосполучення спеціальної мови, створені або запозичені для точного визначення спеціальних понять та позначення спеціальних предметів у 
певній галузі знань. Військова термінологія визначає поняття, безпосередньо пов'язані з військовою справою, засобами ведення збройної боротьби. Військово-технічна термінологія складається 3 науковотехнічних термінів. Військові та військово-технічні терміни обіймають значний обсяг військової лексики, тому що містять максимальне змістове навантаження. Емоційно забарвлена військова лексика, або сленг, - це слова та словосполучення, що вживаються у мовному спілкуванні військовослужбовців і $є$ фактично стилістичними синонімами відповідних військових термінів [2, с. 13-14].

Отже, виходячи з вищесказаного, ми визначаємо військовий термін як стійку одиницю мовної номінації, що закріплена за відповідним поняттям у системі понять певної галузі військової справи і обмежена спеціальною сферою використання у значенні, яке є суворо регламентованим його дефініцією [1, с. 35]. 3 точки зору структури розрізняють односкладні, двоскладні, багатоскладові військові терміни. Основу військової термінології англійської мови складають односкладові і багатокомпонентні номінативні одиниці, які, в основному, представлені субстантивними сполуками. Важливо зазначити, що під час дослідженні кількісного співвідношення компонентів термінів прийменники, сполучники та артиклі розглядалися як складові частини термінів [1, с. 39].

За результатами проведеного дослідження можна навести наступне кількісне співвідношення компонентів військових термінів: 1) 17,80\% займають одно компонентні терміни, 2) 45,80\% складають двокомпонентні терміни, 3) 25,10\% складають трикомпонентні терміни, 4) 7,90\% складають чотирьох компонентні терміни, 5) 2,40\% складають п'яти компоненті терміни, 6) 0,70\% складають шести компоненті терміни, 7) $0,10 \%$ та $0,20 \%$ складають семи та більшкомпоненті терміни. Наведені вище дані чітко ілюструють перевагу двокомпонентних термінів в англомовній військові термінології над іншими категоріями. Перевага цієї категорії термінів зумовлена тим, що двокомпонентні терміни є найбільш простими, прозорими за мотивацією там оптимальними за кількістю.

При розгляді структури військових термінів в розрізі моделей термінотворення у нашому дослідженні серед двокомпонентних термінів було виділено наступні дві, найбільші категорії $\mathrm{N}+\mathrm{N}$ та $\operatorname{Adj}+\mathrm{N}$. 3 загальної суми відібраних термінів 22,6\% складають двокомпонентні терміни 3 моделлю термінотворення N+N. Серед англомовних військових двокомпонентних термінів також поширеними є лексичні одиниці, утворені за моделлю Adj + N. Цей тип словоскладання посідає друге місце за розповсюдженістю. Даний тип словоскладання становить 
20,3\% від загальної кількості термінів відібраних в ході цього дослідження. Серед трикомпонентних термінів розповсюдженими $\epsilon$ моделі $\mathrm{Adj}+\mathrm{N}+\mathrm{N}$, яка складає 9\% від загальної кількості термінів, що були проаналізовані в цьому дослідженні. 8,7\% становить модель термінотворення $\mathrm{N}+\mathrm{N}+\mathrm{N}$. Менш розповсюдженими $\epsilon$ моделі $\mathrm{N}+\mathrm{V}$, $\mathrm{Adj}+\mathrm{Adj}+\mathrm{N}, \operatorname{Adj}+\mathrm{N}+\mathrm{Conj}+\mathrm{N}$.

Висновки. За результатами аналізу відібраних англомовних військових термінів було визначено, що найбільшу кількість становлять двокомпонентні терміни. Трикомпонентні та однокомпонентні становлять меншу частку за двокомпонентні. Як ми можемо помітити, терміни, що являють собою іменникові (субстантивні) словосполучення $\epsilon$ найбільш розповсюдженою категорією термінів у англомовній військовій термінології. Це пояснюється тим, що іменник $є$ однією 3 найпоширеніших частин мови в будь-якій професійній термінології. Результати даного дослідження дають змогу окреслити коло проблем для подальшого опрацювання структурних характеристик військових термінів. В подальшому результати цього дослідження можна використовувати для встановлення спільних та відмінних рис спеціальних та неспеціальних термінів, що функціонують в англомовних текстах військової галузі.

\section{Література:}

1. Василенко Д. В. Розвиток словникового складу англійської мови військової сфери XX - початку XXI століття. Запоріжжя, 2008. 237 с.

2. Нелюбин Л.Л. Военный перевод и его особенности: учебник военного перевода (общий курс). Москва : Воениздат, 1981. 379 с.

3. Скороходько Е. Ф. Сучасна англійська термінологія: [навч. посіб.]. Київ. УІЛМ, 2002. 76 с.

4. Скороходько Е.Ф. Термін у науковому тексті (до створення терміноцентричної теорії наукового дискурсу). Київ: Логос, 2006. 98 с.

5. DOD Dictionary of Military and Associated Terms (DOD Dictionary) URL: https://www.jcs.mil/Portals/36/Documents/Doctrine/pubs/dictionary.pdf

6. Military dictionary by William Duane URL: https://archive.org/details/ 2552043R.nlm.nih.gov/page/n15/mode/2up 